\title{
THE ASSOCIATION BETWEEN ORGANOPHOPHOSPHATE PESTICIDE EXPOSURE AND ERYTHROCYTE SEDIMENTATION RATE AMONG FARMERS IN SUMBEREJO VILLAGE, MAGELANG, CENTRAL JAVA
}

\author{
Desi Putri Utami'), Onny Setiani²), Hanan Lanang Dangiran²), \\ I Made Djaja3) \\ ${ }^{1)}$ Masters Program in Public Health, Faculty of Public Health, Universitas Indonesia \\ ${ }^{2)}$ Department of Health Environment, Universitas Diponegoro \\ 3)Department of Health Environment, Universitas Indonesia
}

\begin{abstract}
Background: The major occupation of Sumberejo villagers is a vegetable farmer. A lot of farmers use organophosphate pesticide spray. Improper use of spraying pesticide may cause harmful health impact in human. Organophophosphate pesticide is poisonous and it affects the blood profile of farmers. This study aimed to examine the association between organophophosphate pesticide exposure and erythrocyte sedimentation rate (ESR) among farmers in Sumberejo Village, Magelang, Central Java.

Subjects and Method: A cross-sectional study was conducted in Sumberejo Village, Magelang, Central Java, on April 2017. A total sample of 43 farmers was selected from a population of 110 farmers for this study by purposive sampling. The dependent variable was ESR. The independent variables were frequency of spraying (exposure/week), number of pesticide, dose of pesticide, length of work (exposure/day), work period (years of exposure), the use of personal protection equipment (PPE), and level of cholinesterase. The ESR data were collected by laboratory test. The other data were collected by questionnaire. The bivariate analysis used the chi-square test.

Results: Frequency of spraying, number of pesticides, length of work, work period, the use of PPE, and level of cholinesterase, were associated with ESR, but they were not statistically significant ( $\mathrm{p}>0.050)$. The association between dose of pesticide and ESR was statistically significant $(\mathrm{p}=0.048)$.

Conclusion: Dose of pesticide is associated with ESR. However, PPE usage, length of work, work period, number of pesticides, frequency of spraying, and level of cholinesterase, do not show statistically significant association with ESR in this study.
\end{abstract}

Keywords: exposure, organophosphate pesticide, erythrocyte sedimentation rate, farmer, level of cholinesterase

Correspondence:

Desi Putri Utami. Masters Program in Public Health, Faculty of Public Health, Universitas Indonesia Depok, West Java. Email: desiputriutami9@gmail.com. Mobile: +6287875941636.

The $6^{\text {th }}$ International Conference on Public Health Best Western Premier Hotel, Solo, Indonesia, October 23-24, 2019 | 25

https://doi.org/10.26911/the6thicph.01.02 